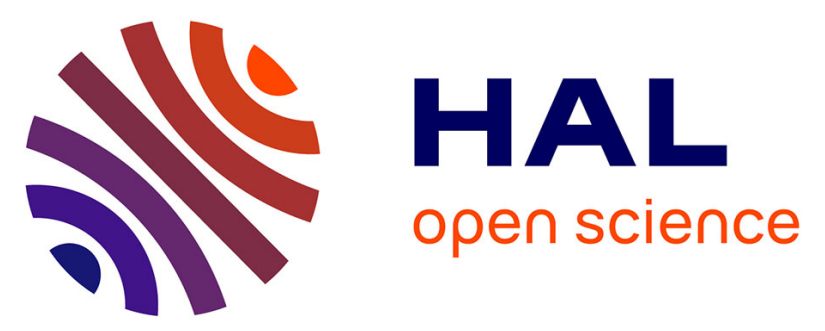

\title{
Air pollution in moderately polluted urban areas: How does the definition of "neighborhood" impact exposure assessment?
}

Quentin Tenailleau, Frédéric Mauny, Daniel Joly, Stéphane François, Nadine Bernard

\section{To cite this version:}

Quentin Tenailleau, Frédéric Mauny, Daniel Joly, Stéphane François, Nadine Bernard. Air pollution in moderately polluted urban areas: How does the definition of "neighborhood" impact exposure assessment?. Environmental Pollution, 2015, 206, pp.437 - 448. 10.1016/j.envpol.2015.07.021 . hal01472575

\section{HAL Id: hal-01472575 \\ https://hal.science/hal-01472575}

Submitted on 20 Feb 2017

HAL is a multi-disciplinary open access archive for the deposit and dissemination of scientific research documents, whether they are published or not. The documents may come from teaching and research institutions in France or abroad, or from public or private research centers.
L'archive ouverte pluridisciplinaire HAL, est destinée au dépôt et à la diffusion de documents scientifiques de niveau recherche, publiés ou non, émanant des établissements d'enseignement et de recherche français ou étrangers, des laboratoires publics ou privés. 


\title{
Air pollution in moderately polluted urban areas: How does the definition of "neighborhood" impact exposure assessment?
}

\author{
Quentin M. Tenailleau ${ }^{\text {a, }}{ }^{\text {, }}$, Frédéric Mauny ${ }^{\mathrm{a}, \mathrm{b}}$, Daniel Joly ${ }^{\mathrm{c}}$, Stéphane François ${ }^{\mathrm{d}}$, \\ Nadine Bernard ${ }^{\mathrm{a}, \mathrm{c}}$ \\ a Laboratoire Chrono-environnement, UMR6249, Centre National de la Recherche Scientifique, Université de Bourgogne/Franche-Comté, France \\ b Centre Hospitalier Régional Universitaire de Besançon, France \\ ' Laboratoire ThéMA, UMR6049, Centre National de la Recherche Scientifique, Université de Bourgogne/Franche-Comté, France \\ d AASQA Atmo Franche-Comté, France
}

\section{A R T I C L E I N F O}

\section{Article history:}

Received 25 June 2015

Accepted 16 July 2015

Available online $\mathrm{xxx}$

\section{Keywords:}

Environmental exposure assessment

techniques

Living neighborhood

Urban environmental parameters

Outdoor air pollution

Multiple-exposure

\begin{abstract}
A B S T R A C T
Environmental health studies commonly quantify subjects' pollution exposure in their neighborhood. How this neighborhood is defined can vary, however, leading to different approaches to quantification whose impacts on exposure levels remain unclear. We explore the relationship between neighborhood definition and exposure assessment. $\mathrm{NO}_{2}$, benzene, $\mathrm{PM}_{10}$ and $\mathrm{PM}_{2.5}$ exposure estimates were computed in the vicinity of 10,825 buildings using twelve exposure assessment techniques reflecting different definitions of "neighborhood". At the city scale, its definition does not significantly influence exposure estimates. It does impact levels at the building scale, however: at least a quarter of the buildings' exposure estimates for a $400 \mathrm{~m}$ buffer differ from the estimated $50 \mathrm{~m}$ buffer value $\left( \pm 1.0 \mu \mathrm{g} / \mathrm{m}^{3}\right.$ for $\mathrm{NO}_{2}$, $\mathrm{PM}_{10}$ and $\mathrm{PM}_{2.5}$; and $\pm 0.05 \mu \mathrm{g} / \mathrm{m}^{3}$ for benzene). This variation is significantly related to the definition of neighborhood. It is vitally important for investigators to understand the impact of chosen assessment techniques on exposure estimates.
\end{abstract}

๑) 2015 Elsevier Ltd. All rights reserved.

\section{Introduction}

Studies in environmental epidemiology have long identified the negative effects of outdoor air pollution on human health (Brunekreef and Holgate, 2002), (Health Effects Institute, 2000), (World Health Organization Europe, 2003), and the WHO recently recognized outdoor air pollution as a cause of cancer (World Health Organization, 2013). The dose/response relationship does not indicate a threshold, and health effects have been found at concentrations as low as background levels (World Health Organization Europe, 2000), (World Health

\footnotetext{
* Corresponding author. Laboratoire Chrono-Environnement (UMR6249), Centre de Méthodologie Clinique, CHRU, Hôpital St. Jacques, 2 place Saint Jacques, F-25030 Besançon Cedex, France.

E-mail address: quentin.tenailleau@univ-fcomte.fr (Q.M. Tenailleau).
}

Organization Europe, 2003), (World Health Organization Europe, 2005a).

In Europe, cities of 100,000 to 500,000 inhabitants are considered to be "medium sized" (Boddy, 1999). They are the largest category of city in demographic terms, hosting more than $44 \%$ of the European population (Giffinger et al., 2007). However, most environmental epidemiological studies have been conducted in major cities ( $>500,000$ inhabitants), where population size and local activities directly impact anthropogenic pollutant emissions (Ehrlich and Holdren, 1974), (Selden and Song, 1994), (EEA, 2009), (EMEP/EEA, 2013). Smaller cities then tend to have lower background concentrations than major cities (Shukla and Parikh, 1992). In the short term, though, efforts to consistently lower legal threshold limit values should lead major cities' air pollution levels to decline to the levels currently observed in medium-sized cities. This makes today's medium-sized cities good places for studying exposure to future concentrations in 
major cities.

A subject spends an average of $70 \%$ of his time-budget at home (Klepeis et al., 2001), (European Commission, 2004). Consequently, population-based studies have come to use the subject's home or its vicinity as the basis for exposure assessment. Assessing exposure for large samples of subjects is typically approached using environmental contamination modeling (Nieuwenhuijsen et al., 2006), (Auchincloss et al., 2012). The model approach uses the composition of the selected environment (pollution sources, topography, urban morphology, meteorology, etc.) to calculate outdoor atmospheric pollutant concentrations. An exposure assessment is then obtained by calculating the pollutant concentrations of an area associated with each subject's residential building. The definition of this area differs according to the study, from a single point to a wide area that might correspond to the entire city or beyond. Therefore, the quality of exposure assessment greatly depends on the accuracy and scale of the model, and on the spatial definition of the neighborhood (Nieuwenhuijsen, 2003) In this study, we consider the living neighborhood as the spatial unit in which subjects live and meet most of their daily needs (Smith et al., 2010), (Duncan et al., 2014).

Epidemiological studies most commonly use the geocoded home address point to represent the living neighborhood (Hoek et al., 2002), (Hoffmann et al., 2009), but there are other definitions based on buffer radii around buildings (Cesaroni et al., 2008) or officially designated administrative areas (Huynh et al., 2006), (Bell et al., 2007). The consequences of such a choice on exposure assessment are largely unknown. Our team recently studied the influence of the spatial definition of neighborhood on environmental noise exposure (Tenailleau et al., 2015). To our knowledge, no studies to date have addressed how the definition of neighborhood impacts estimates of air pollution exposure levels, and only one study examined the impact of neighborhood scale on the relationship between socioeconomic status and $\mathrm{NO}_{2}$ concentrations (Stroh et al., 2005).

This article aims to explore the relationship between the definition of living neighborhood and air pollution exposure estimates in the setting of a medium-sized, moderately polluted European city. The present study focuses on four traffic-related pollutants of different kinds and particle sizes $\left(\mathrm{NO}_{2}\right.$, benzene, $\mathrm{PM}_{10}$ and $\mathrm{PM}_{2.5}$.

\section{Materials \& methods}

\subsection{Study site}

Besançon is the capital of the Franche-Comté, a French administrative region in eastern France (Lat: 47.237829, Long: 6.024054 in WGS84, see Appendix 1). It is a medium-sized city of approximately 118,000 inhabitants (INSEE, 2009) and a surface area of $65 \mathrm{~km}^{2}$. Road traffic is its main source of environmental air pollution, and it has no other significant pollutionproducing infrastructure such as airports or large highways.

\subsection{Air pollution models}

Four pollutants related to road traffic were studied, chosen from the three main known pollutant types. $\mathrm{NO}_{2}$ is a gaseous pollutant known to be the main indicator of road traffic (EEA, 2011a). Benzene is a volatile organic compound closely related to road traffic and residential heating (EEA, 2011a). Particulate matter $\left(\mathrm{PM}_{10}\right)$ and fine particulate matter $\left(\mathrm{PM}_{2.5}\right)$ are also generated by road traffic and residential heating and were chosen because of their significant impact on human health and climate (World Health Organization Europe, 2003), (EEA, 2011b).

Citywide air pollution levels for the year 2011 were calculated using a three-step method developed in collaboration with ATMO Franche-Comté, Besançon's air-quality monitoring network (see Appendix 2). Briefly, the annual daily average of road traffic emissions was first evaluated by entering road traffic data provided by city agencies and the Interprofessional Technical Centre for Air Pollution Studies (CITEPA) into the pollutant emission modeling software Circul'Air, developed by the air quality monitoring network of Alsace based on the COPERT4 European standard methodology (EMEP/EEA, 2009) (Pujol et al., 2012). In the meantime, pollution from heating and industrial emissions and long-range sources were evaluated for each census block using ATMO Franche-Comté databases. This emissions data and a set of environmental data were then entered in ADMSUrban $\odot$, air pollution modelling software developed in accordance with WHO guidelines by the Cambridge Environmental Research Consultants company. This software is widely used in Europe for modelling air quality on scales ranging from large urban areas to the street level (Cambridge Environmental Research Consultants, 2014). Finally, ESRI arcGIS@ (V9.3.1) software was used with ADMS-Urban $\odot$ output to produce a $4 \mathrm{~m}^{2}$ $(2 \mathrm{~m} \times 2 \mathrm{~m})$ raster grid with each pixel giving an air pollution level in microgram $/ \mathrm{m}^{3}$ at $2 \mathrm{~m}$ above ground level.

\subsection{Model validation}

$\mathrm{NO}_{2}$ and benzene models were validated using 800 measurement values obtained from four two-week pollution field surveys in autumn and winter 2010 and spring and summer 2011 (Spearman's rho $=0.80$ and 0.82 , for $\mathrm{NO}_{2}$ and benzene respectively, all $\mathrm{p}<0.01)$. ATMO Franche-Comté conducted this study using passive samplers at 200 locations (mostly at posts and signs) chosen to represent different positions relative to the nearby sources. The validity of the $\mathrm{PM}_{2.5}$ and $\mathrm{PM}_{10}$ models were verified using the city's fixed air-quality monitoring network.

\subsection{Quantifying air pollution exposure}

Following a previously described methodology (Tenailleau et al., 2015), the study considered the city's 10,825 residential buildings found within city limits, excluding those inside but within $400 \mathrm{~m}$ of the boundary (whose buffer radius would have surpassed city limits) (see Appendix 3). For each building, twelve exposure estimates were calculated based on assessment techniques commonly used in epidemiological studies: address point $(n=1)$, the building's external perimeter $(n=1)$, the living neighborhood buffer $(n=8)$, and administrative areas $(n=2)$.

- The address-point technique estimates environmental exposure using the single pixel corresponding to the building's geolocalized address in official databases.

- The building's external perimeter technique estimates environmental exposure using all pixels located from 0 to $6 \mathrm{~m}$ from the building's walls.

- Buffer techniques use a variety of living neighborhood buffers to estimate environmental exposure around the building within a given radius. Eight buffer radii were defined to assess the influence of spatial scale on the 
quantification of pollutants: $50 \mathrm{~m}, 100 \mathrm{~m}, 150 \mathrm{~m}, 200 \mathrm{~m}$, $250 \mathrm{~m}, 300 \mathrm{~m}, 350 \mathrm{~m}$ and $400 \mathrm{~m}$. Each radius corresponds to a single exposure estimate calculation.

- Lastly, administrative area techniques were based on two official French administrative scales: census blocks (INSEE, 2013a) and census block groups (INSEE, 2013b). Each building was assigned two exposure estimates corresponding to the two administrative levels in which it is located.

For each pollutant, the twelve exposure estimates were calculated by averaging the pollution value of each pixel in the area relevant to the technique. Consequently, each exposure estimate stood for a different conception of the building's "neighborhood."

\subsection{Urban physical and socio-economic variables}

Two variables were defined at the building level: the distance between each building and the nearest road, and the distance between the building and the nearest main road, defined as a road with more than 5000 vehicles/day. Each census block was characterized using an urban typology based on its build-up pattern, building density, and human land use (Houot, 1999), (Tenailleau et al., 2015). The five classes were Individual Housing, Densely Urbanized Areas, Social Housing, Mixed Residential Areas, and Activity Centers (see Appendix 4 \& Appendix 5). Each census block group was defined using socio-economic data from the INSEE 2009 census database (INSEE, 2009). Nine variables were retained: population density plus eight deprivation indices - the Gini coefficient of salary inequality, unemployment rate, percentage of homeowners, percentage of households without a car, percentage of laborer households, percentage of single parents, percentage of foreign nationals (INSEE, 2013c) and percentage of immigrants (regardless of citizenship status) (INSEE, 2013d).

\subsection{Statistical analysis}

Multilevel modeling was used to explore the relationship between exposure estimates and urban physical and socioeconomic variables. Firstly, the heterogeneity of exposure estimate samples was tested for differences between pollutants, using random coefficients introduced and tested through multilevel linear modeling. Secondly, for each pollutant the differences between the 12 exposure estimates were assessed using pairwise equivalence tests. The large number of buildings retained for analysis ( $n=10,825)$ may produce significant results despite their metrological insignificance. To adjust the statistical results to actual outdoor pollution concentrations, the mean differences between modeled exposures were only considered significant if they were not included in a chosen zone of equivalence. Zone of

Table 1

$\mathrm{NO}_{2}$, benzene, $\mathrm{PM}_{10}$ and $\mathrm{PM}_{2.5}$ exposure estimate sample distribution, according to the surface area of exposure techniques ( $\mathrm{n}=10,825$ ).

\begin{tabular}{|c|c|c|c|c|c|c|c|c|c|c|c|c|}
\hline & $\begin{array}{l}\text { Address } \\
\text { points }\end{array}$ & $\begin{array}{l}\text { Building } \\
\text { perimeter }\end{array}$ & $\begin{array}{l}50 \mathrm{~m} \\
\text { Buffer }\end{array}$ & $\begin{array}{l}100 \mathrm{~m} \\
\text { Buffer }\end{array}$ & $\begin{array}{l}150 \mathrm{~m} \\
\text { Buffer }\end{array}$ & $\begin{array}{l}200 \mathrm{~m} \\
\text { Buffer }\end{array}$ & $\begin{array}{l}250 \mathrm{~m} \\
\text { Buffer }\end{array}$ & $\begin{array}{l}300 \mathrm{~m} \\
\text { Buffer }\end{array}$ & $\begin{array}{l}350 \mathrm{~m} \\
\text { Buffer }\end{array}$ & $\begin{array}{l}400 \mathrm{~m} \\
\text { Buffer }\end{array}$ & $\begin{array}{l}\text { Census } \\
\text { blocks }\end{array}$ & $\begin{array}{l}\text { Census block } \\
\text { groups }\end{array}$ \\
\hline \multicolumn{13}{|l|}{ Considered surface area } \\
\hline $\begin{array}{l}\text { Average living surface } \\
\text { area }\left(\mathrm{m}^{2}\right)^{*}\end{array}$ & 4.0 & 507.1 & 5733.5 & $24,120.4$ & $55,376.3$ & $99,916.3$ & $157,645.1$ & $227,374.2$ & $313,032.9$ & $410,203.1$ & $63,145.1$ & $842,440.3$ \\
\hline \multicolumn{13}{|l|}{$\mathrm{NO}_{2}$} \\
\hline Min-Max & $8.8-44.6$ & $8.6-48.8$ & $8.7-46.4$ & $8.8-43.9$ & $8.8-40.7$ & $8.7-39.2$ & $8.7-37.7$ & $8.7-36$ & $8.7-34.9$ & $8.7-34.1$ & $8.8-43.8$ & $10.7-37.1$ \\
\hline Mean (S.D.) & $18.5(5.2)$ & $17.8(4.8)$ & $\begin{array}{l}18.1 \\
(5.2)\end{array}$ & $18.2(5.1)$ & $18.3(5.0)$ & $18.4(5.0)$ & $18.4(5.0)$ & $18.5(4.9)$ & $18.5(4.8)$ & $18.5(4.8)$ & $18.2(5.1)$ & $17.7(4.9)$ \\
\hline $\begin{array}{l}\text { 1st Quartile - 3rd } \\
\text { Quartile }\end{array}$ & $14.5-21.5$ & $14.1-20.7$ & $\begin{array}{l}14.1 \\
-21.0\end{array}$ & $\begin{array}{l}14.2 \\
-21.3\end{array}$ & $\begin{array}{l}14.1 \\
-21.4\end{array}$ & $\begin{array}{l}14.2 \\
-21.5\end{array}$ & $\begin{array}{l}14.3 \\
-21.5\end{array}$ & $\begin{array}{l}14.4 \\
-21.6\end{array}$ & $\begin{array}{l}14.5 \\
-21.7\end{array}$ & $\begin{array}{l}14.7 \\
-21.6\end{array}$ & $14.1-21.4$ & $13.9-21.2$ \\
\hline Median & 18.2 & 17.7 & 17.8 & 18.0 & 18.3 & 18.6 & 18.6 & 18.7 & 18.7 & 18.7 & 18.2 & 18.0 \\
\hline $\begin{array}{l}\text { Variation Coefficient } \\
\text { Benzene }\end{array}$ & 28.1 & 27.2 & 28.7 & 28.0 & 27.3 & 27.2 & 27.2 & 26.5 & 26.0 & 25.9 & 28.0 & 27.7 \\
\hline Min-Max & $1.0-1.6$ & $1.0-1.8$ & $1.0-1.8$ & $1.0-1.7$ & $1.0-1.6$ & $1.0-1.6$ & $1.0-1.6$ & $1.0-1.5$ & $1.0-1.5$ & $1.0-1.5$ & $1.0-1.7$ & $1.0-1.5$ \\
\hline Mean (S.D.) & $1.2(0.1)$ & $1.2(0.1)$ & $1.2(0.1)$ & $1.2(0.1)$ & $1.2(0.1)$ & $1.2(0.1)$ & $1.2(0.1)$ & $1.2(0.1)$ & $1.2(0.1)$ & $1.2(0.1)$ & $1.2(0.1)$ & $1.2(0.1)$ \\
\hline $\begin{array}{l}\text { 1st Quartile - 3rd } \\
\text { Quartile }\end{array}$ & $1.1-1.3$ & $1.1-1.3$ & $1.1-1.3$ & $1.1-1.3$ & $1.1-1.3$ & $1.1-1.3$ & $1.1-1.3$ & $1.1-1.3$ & $1.1-1.3$ & $1.1-1.3$ & $1.1-1.3$ & $1.1-1.3$ \\
\hline Median & 1.2 & 1.2 & 1.2 & 1.2 & 1.2 & 1.2 & 1.2 & 1.2 & 1.2 & 1.2 & 1.2 & 1.2 \\
\hline $\begin{array}{l}\text { Variation Coefficient } \\
\mathbf{P M}_{10}\end{array}$ & 8.3 & 8.3 & 8.3 & 8.3 & 8.3 & 8.3 & 8.3 & 8.3 & 8.3 & 8.3 & 8.3 & 8.3 \\
\hline Min-Max & $17.7-30.1$ & $17.7-30.7$ & $\begin{array}{l}17.7 \\
-30.0\end{array}$ & $\begin{array}{l}17.7 \\
-27.7\end{array}$ & $\begin{array}{l}17.7 \\
-27.5\end{array}$ & $\begin{array}{l}17.7 \\
-26.7\end{array}$ & $\begin{array}{l}17.7 \\
-26.3\end{array}$ & $\begin{array}{l}17.7 \\
-25.4\end{array}$ & $\begin{array}{l}17.7 \\
-24.7\end{array}$ & $\begin{array}{l}17.7 \\
-24.2\end{array}$ & $17.7-27.8$ & $18.3-25.5$ \\
\hline Mean (S.D.) & $20.9(1.6)$ & $20.6(1.4)$ & $\begin{array}{l}20.7 \\
(1.5)\end{array}$ & $20.7(1.5)$ & $20.8(1.5)$ & $20.8(1.4)$ & $20.8(1.5)$ & $20.8(1.4)$ & $20.8(1.4)$ & $20.8(1.4)$ & $20.7(1.5)$ & $20.6(1.5)$ \\
\hline $\begin{array}{l}\text { 1st Quartile - 3rd } \\
\text { Quartile }\end{array}$ & $19.7-21.7$ & $19.6-21.4$ & $\begin{array}{l}19.6 \\
-21.5\end{array}$ & $\begin{array}{l}19.6 \\
-21.6\end{array}$ & $\begin{array}{l}19.6 \\
-21.7\end{array}$ & $\begin{array}{l}19.7 \\
-21.7\end{array}$ & $\begin{array}{l}19.7 \\
-21.7\end{array}$ & $\begin{array}{l}19.7 \\
-21.8\end{array}$ & $\begin{array}{l}19.7 \\
-21.8\end{array}$ & $\begin{array}{l}19.7 \\
-21.9\end{array}$ & $19.7-21.6$ & $19.4-21.6$ \\
\hline Median & 20.6 & 20.4 & 20.5 & 20.6 & 20.7 & 20.8 & 20.8 & 20.9 & 20.9 & 20.9 & 20.7 & 20.7 \\
\hline $\begin{array}{l}\text { Variation Coefficient } \\
\mathbf{P M}_{2.5}\end{array}$ & 7.4 & 6.9 & 6.8 & 6.8 & 6.8 & 6.8 & 6.8 & 6.8 & 6.2 & 6.2 & 6.8 & 6.3 \\
\hline Min-Max & $13.8-22.6$ & $13.8-23.3$ & $\begin{array}{l}13.8 \\
-22.8\end{array}$ & $\begin{array}{l}13.8 \\
-21.2\end{array}$ & $\begin{array}{l}13.8 \\
-21.1\end{array}$ & $\begin{array}{l}13.8 \\
-20.5\end{array}$ & $\begin{array}{l}13.8 \\
-20.1\end{array}$ & $\begin{array}{l}13.8 \\
-19.5\end{array}$ & $13.8-19$ & $\begin{array}{l}13.8 \\
-18.6\end{array}$ & $13.8-21.3$ & $14.3-19.6$ \\
\hline Mean (S.D.) & $16.2(1.2)$ & $16.0(1.1)$ & $\begin{array}{l}16.1 \\
(1.1)\end{array}$ & $16.1(1.1)$ & $16.1(1.1)$ & $16.2(1.1)$ & $16.2(1.1)$ & $16.2(1.1)$ & $16.2(1.0)$ & $16.2(1.0)$ & $16.1(1.1)$ & $16.0(1.0)$ \\
\hline $\begin{array}{l}\text { 1st Quartile - 3rd } \\
\text { Quartile }\end{array}$ & $15.4-16.8$ & $15.2-16.6$ & $\begin{array}{l}15.3 \\
-16.7\end{array}$ & $\begin{array}{l}15.3 \\
-16.8\end{array}$ & $\begin{array}{l}15.3 \\
-16.8\end{array}$ & $\begin{array}{l}15.3 \\
-16.9\end{array}$ & $\begin{array}{l}15.4 \\
-16.9\end{array}$ & $\begin{array}{l}15.4 \\
-16.9\end{array}$ & $\begin{array}{l}15.4 \\
-16.9\end{array}$ & $\begin{array}{l}15.4 \\
-16.9\end{array}$ & $15.3-16.7$ & $15.2-16.8$ \\
\hline Median & 16.1 & 15.9 & 16.0 & 16.0 & 16.1 & 16.2 & 16.2 & 16.3 & 16.3 & 16.3 & 16.1 & 16.1 \\
\hline Variation Coefficient & 7.7 & 6.8 & 7.3 & 7.3 & 7.2 & 6.7 & 7.2 & 6.7 & 6.7 & 6.7 & 7.3 & 7.3 \\
\hline
\end{tabular}

* Living surface area = total surface area considered by the chosen technique minus built surface area. 

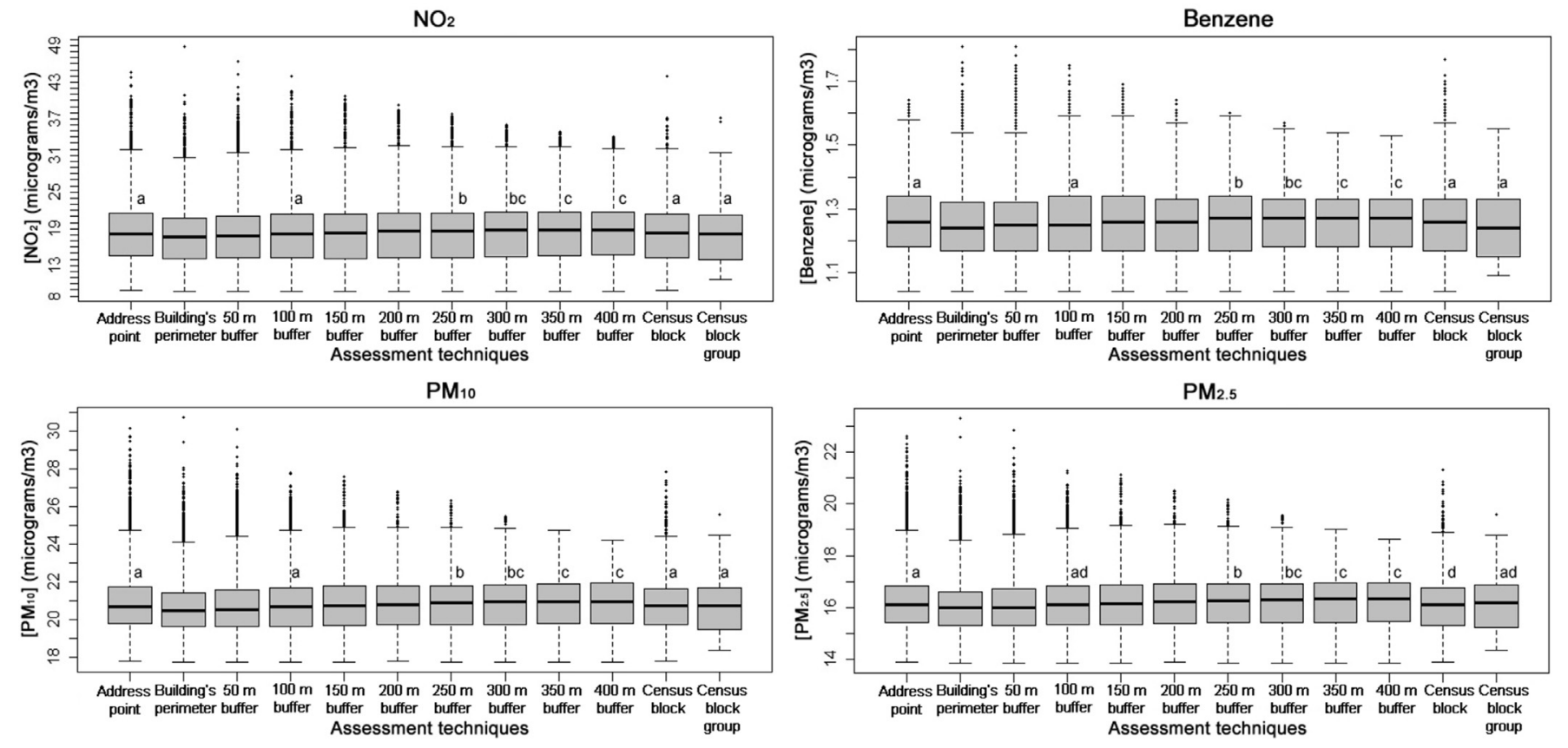

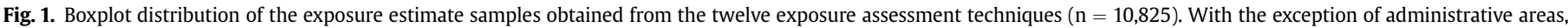
they are organized by increasing surface area.

equivalence limits were chosen in accordance with the metrological limits of common passive sampler tools (Rupprecht and Patashnick Co., Inc., 2009), (Passam ag, 2010), (Centro di Ricerche Ambientali - Padova, 2006). A conservative approach was chosen because modeling approaches are known for being less precise than sampling approaches. Consequently, the 95\% confidence intervals $(95 \% \mathrm{CI})$ for the mean differences were calculated and compared with the zone of equivalence of $\left[-1.0 \mu \mathrm{g} / \mathrm{m}^{3} ;+1.0 \mu \mathrm{g} / \mathrm{m}^{3}\right]$ for $\mathrm{NO}_{2}, \mathrm{PM}_{10}$ and $\mathrm{PM}_{2.5}$ and $[-0.1 \mu \mathrm{g} /$ $\left.\mathrm{m}^{3} ;+0.1 \mu \mathrm{g} / \mathrm{m}^{3}\right]$ for benzene. If the $95 \% \mathrm{CI}$ of the mean difference was entirely within the zone of equivalence, the means were considered equivalent.

To assess the potential impact of a change in the size of the sampled area, the variation between exposure estimates at the $50 \mathrm{~m}$ buffer and the $400 \mathrm{~m}$ buffer was calculated for each pollutant using the following formula $\left(\Delta_{400-50}=\right.$ [pollutant $\left.]_{400 \mathrm{~m}}-[\text { pollutant }]_{50 \mathrm{~m}}\right)$. Next, the relation between urban environmental characteristics and $\Delta_{400-50}$ was tested using multilevel linear regression models. Statistical analyses were carried out using the $\mathrm{R}$ statistics software (V3.0.0) and MLwiN (V2.28). The significance level for all tests was set at 0.05 .

\section{Results}

Air pollution exposure estimates obtained from the selected assessment techniques are presented in Table 1 and Fig. 1. Levels for all pollutants were low and show low heterogeneity both within samples and between samples. The values for $\mathrm{NO}_{2}$ presented the highest heterogeneity of all the pollutants $\left(\mathrm{p}<10^{-3}\right)$. For each pollutant, pairwise comparisons of the twelve means demonstrated the equivalency of the exposure estimates. All of the 95\% Confidence Intervals of mean differences were entirely within the chosen zones of equivalence of $\left[-1.0 \mu \mathrm{g} / \mathrm{m}^{3} ;+1.0 \mu \mathrm{g} /\right.$ $\left.\mathrm{m}^{3}\right]$ for $\mathrm{NO}_{2}, \mathrm{PM}_{10}$ and $\mathrm{PM}_{2.5}$ and $\left[-0.1 \mu \mathrm{g} / \mathrm{m}^{3} ;+0.1 \mu \mathrm{g} / \mathrm{m}^{3}\right]$ for benzene.

Table 2

Distribution of the $\Delta_{400-50}$ for each pollutant ( $\mathrm{n}=10,825$ ).

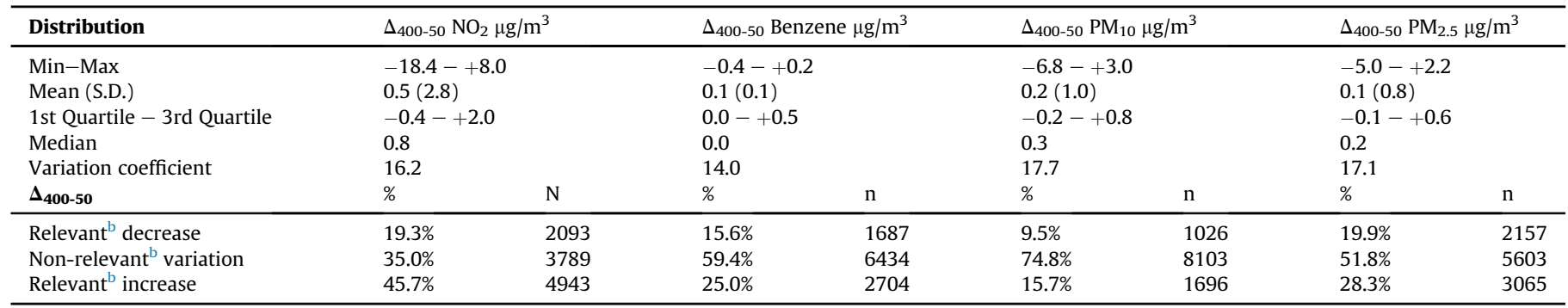

a $\Delta_{400-50}=$ the difference between the exposure estimate at the $400 \mathrm{~m}$ buffer and the $50 \mathrm{~m}$ buffer.

b $\Delta_{400-50}$ are considered to be irrelevant between $\left[-1.0 \mu \mathrm{g} / \mathrm{m}^{3} ;+1.0 \mu \mathrm{g} / \mathrm{m}^{3}\right]$ for $\mathrm{NO}_{2}, \mathrm{PM}_{10}$ and $\mathrm{PM}_{2.5}$ and between $\left[-0.1 \mu \mathrm{g} / \mathrm{m}^{3} ;+0.1 \mu \mathrm{g} / \mathrm{m}^{3}\right]$ for benzene. 


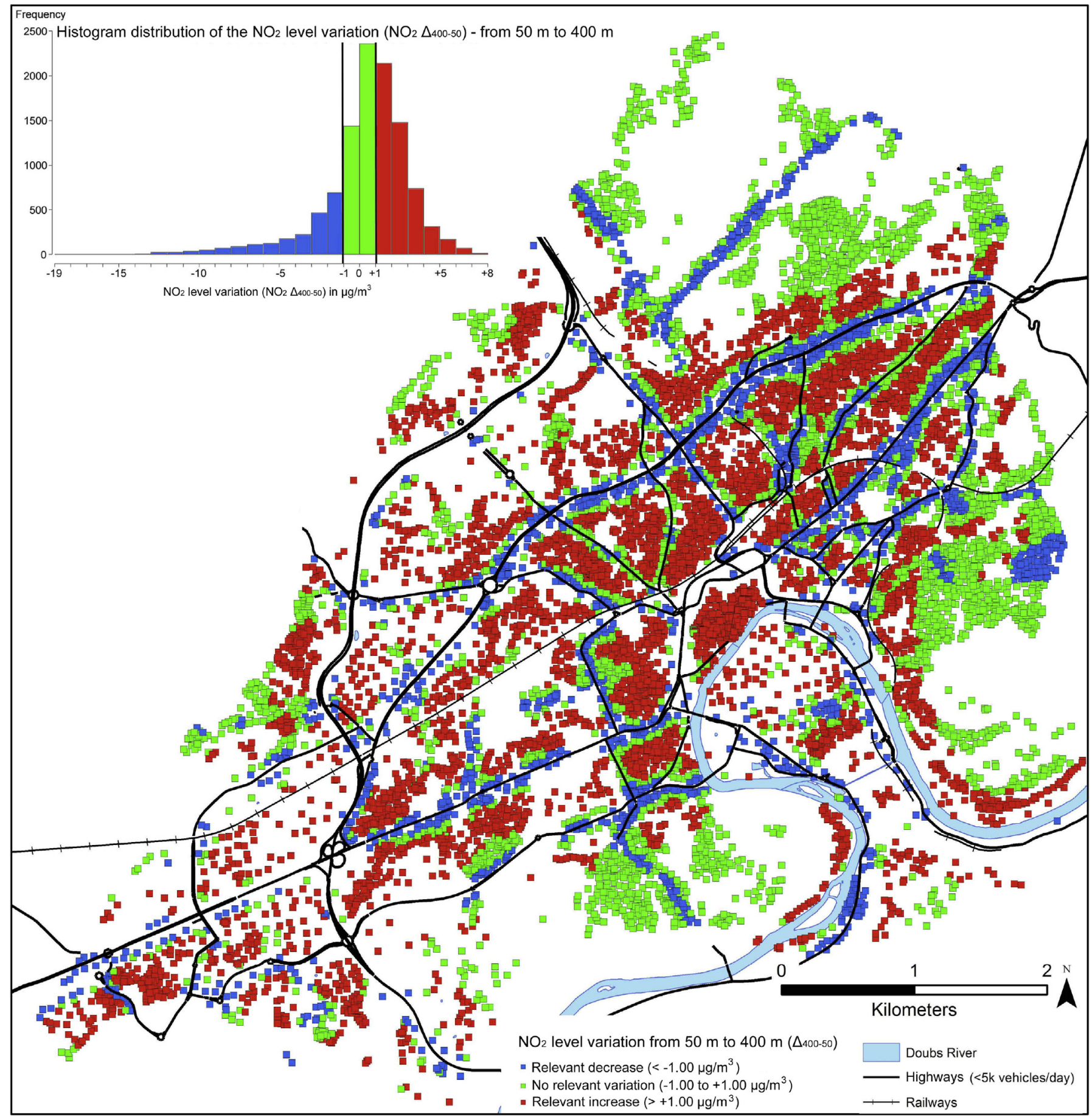

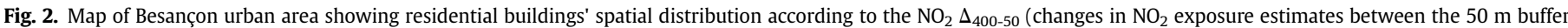

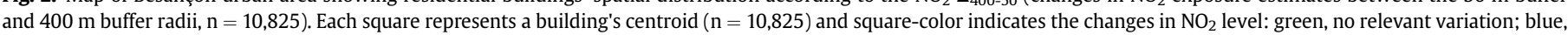
relevant decrease; red, relevant increase.

Differences between the exposure estimates at the $400 \mathrm{~m}$ radius buffer and the $50 \mathrm{~m}$ radius buffer (the $\Delta_{400-50}$ ) for all four pollutants are presented in Table 2 and Fig. 2. For $\mathrm{NO}_{2}, 65 \%$ of buildings presented a $\Delta_{400-50}$ higher than the $\left|1.0 \mu \mathrm{g} / \mathrm{m}^{3}\right|$ value chosen for this pollutant. Such change concerned $25.1 \%$ for $\mathrm{PM}_{10}$ and $48.2 \%$ for $\mathrm{PM}_{2.5}$; it also concerned $40.6 \%$ of buildings for benzene, using a $\left|0.1 \mu \mathrm{g} / \mathrm{m}^{3}\right|$ value. The observed $\Delta_{400-50}$ (in $\mu \mathrm{g} / \mathrm{m}^{3}$ ) ranged from -18.4 to $+8.0\left(\mathrm{NO}_{2}\right),-0.4$ to +0.2 (benzene), -6.8 to $+3.3\left(\mathrm{PM}_{10}\right)$ and -5.0 to +2.2 $\left(\mathrm{PM}_{2.5}\right)$.

The relationship between $\Delta_{400-50}$ and the urban physical and socio-economic variables are summarized in Table 3 (see also Appendices 3 and 4). Unsurprisingly, the distance between the building and road significantly and positively correlated to $\Delta_{400-}$ 50 for all pollutants. However, differences appear in correlations with urban typology, population density and deprivation indices, 
Table 3

Multilevel analysis of $\mathrm{NO}_{2} \Delta_{400-50}$ (change in $\mathrm{NO}_{2}$ level between the $50 \mathrm{~m}$ buffer and the $400 \mathrm{~m}$ buffer, $\mathrm{n}=10,825$ ).

\begin{tabular}{|c|c|c|c|c|c|c|c|c|c|c|c|c|c|}
\hline \multirow[b]{2}{*}{ Level } & \multirow[b]{2}{*}{ Variable } & \multicolumn{3}{|c|}{$\Delta_{400-50} \mathrm{NO}_{2}$} & \multicolumn{3}{|c|}{$\Delta_{400-50}$ Benzene } & \multicolumn{3}{|c|}{$\Delta_{400-50} \mathrm{PM}_{10}$} & \multicolumn{3}{|c|}{$\Delta_{400-50} \mathrm{PM}_{2.5}$} \\
\hline & & $\beta$ & SD & P-value & $\beta$ & SD & P-value & $\beta$ & SD & P-value & $\beta$ & SD & P-value \\
\hline \multirow[t]{2}{*}{ Building } & Distance to nearest road (for $+100 \mathrm{~m}$ ) & 9.70 & 0.53 & $<0.01$ & 4.35 & 0.22 & $<0.01$ & 3.43 & 0.20 & $<0.01$ & 3.29 & 0.19 & $<0.01$ \\
\hline & Distance to nearest main road (for $+100 \mathrm{~m}$ ) & 4.30 & 0.12 & $<0.01$ & 1.63 & 0.05 & $<0.01$ & 1.52 & 0.04 & $<0.01$ & 1.45 & 0.04 & $<0.01$ \\
\hline \multirow[t]{5}{*}{ Census Blocks } & Urban typology (Ref: Individual Housing) & & & 0.22 & & & $<0.01$ & & & $<0.01$ & & & $<0.01$ \\
\hline & Densely Urbanized Area & 1.49 & 1.91 & & 1.02 & 0.79 & & 1.05 & 0.75 & & 0.98 & 0.72 & \\
\hline & Social Housing & 2.92 & 1.89 & & 2.87 & 0.78 & & 2.15 & 0.74 & & 2.08 & 0.70 & \\
\hline & Mixed Residential Area & 1.29 & 1.50 & & 0.39 & 0.62 & & 0.33 & 0.58 & & 0.30 & 0.56 & \\
\hline & Activity Center & -3.75 & 2.83 & & -1.22 & 1.17 & & -1.38 & 1.11 & & -1.25 & 1.06 & \\
\hline \multirow[t]{9}{*}{ C. Block Groups } & Population density (for $+1000 \mathrm{hab} / \mathrm{Km}^{2}$ ) & 0.10 & 0.13 & 0.44 & 0.14 & 0.05 & $<0.01$ & 0.14 & 0.05 & $<0.01$ & 0.14 & 0.05 & $<0.01$ \\
\hline & Gini income inequality coefficient & 16.14 & 7.69 & 0.04 & 7.65 & 3.34 & 0.02 & 8.34 & 3.12 & $<0.01$ & 8.07 & 2.97 & $<0.01$ \\
\hline & Unemployment rate (for $+10 \%$ ) & 2.20 & 1.01 & 0.03 & 1.50 & 0.40 & $<0.01$ & 1.50 & 0.40 & $<0.01$ & 1.40 & 0.40 & $<0.01$ \\
\hline & Percentage of homeowners (for $+10 \%$ ) & -0.70 & 0.35 & 0.05 & -0.39 & 0.16 & 0.02 & -0.43 & 0.14 & $<0.01$ & -0.42 & 0.14 & $<0.01$ \\
\hline & Percentage of households without car (for $+10 \%$ ) & 1.00 & 0.54 & 0.06 & 0.61 & 0.24 & 0.01 & 0.67 & 0.22 & $<0.01$ & 0.64 & 0.21 & $<0.01$ \\
\hline & Percentage of laborer households (for $+10 \%$ ) & 1.30 & 0.90 & 0.17 & 1.10 & 0.40 & $<0.01$ & 1.00 & 0.40 & $<0.01$ & 1.00 & 0.40 & $<0.01$ \\
\hline & Percentage of single-parent families (for $+10 \%$ ) & 1.40 & 0.90 & 0.11 & 1.00 & 0.40 & $<0.01$ & 1.00 & 0.40 & $<0.01$ & 1.00 & 0.30 & $<0.01$ \\
\hline & Percentage of foreign nationals (for $+10 \%$ ) & 2.70 & 1.22 & 0.03 & 1.60 & 0.50 & $<0.01$ & 1.60 & 0.50 & $<0.01$ & 1.60 & 0.50 & $<0.01$ \\
\hline & Percentage of immigrants (for $+10 \%$ ) & 2.40 & 1.01 & 0.02 & 1.40 & 0.40 & $<0.01$ & 1.40 & 0.40 & $<0.01$ & 1.40 & 0.40 & $<0.01$ \\
\hline
\end{tabular}

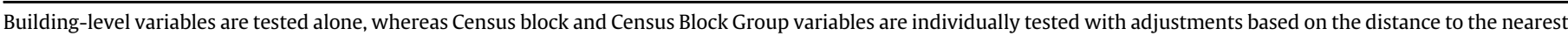
road.

depending on the pollutant. Fig. 2 illustrates the relationship between $\mathrm{NO}_{2} \Delta_{400-50}$ and the urban environment for all 10,825 residential buildings. Increases or decreases in buildings' $\mathrm{NO}_{2}$ exposure estimates when evaluated at a larger radius buffer appear to be related to their spatial position. Due to the change in the considered neighborhood's surface, buildings along main roads exhibit a decrease in $\mathrm{NO}_{2}$ exposure estimates (blue squares), and those inside blocks exhibit an increase (red squares).

\section{Discussion}

Depending on the scale of observation, the definition of "living neighborhood" has a variable effect on exposure estimates for the four pollutants. Initial results showing very similar average values between exposure estimates could lead to the false conclusion that there is no connection between chosen assessment techniques, neighborhood definition, and obtained exposure estimates. Conversely, at the scale of the individual building, the surface area used to define the living neighborhood is significantly influential.

The four air pollution models used in this study were built using the same data sets and software, both commonly used by French air quality monitoring services. The models were validated using data obtained through an extensive four-season field measurement campaign of pollution levels and/or the city's stationary air-quality monitoring network. The emissiondispersion pattern of all four air pollutant values aligns with other urban areas (World Health Organization Europe, 2005b), (Clougherty et al., 2008), (Zhang and Batterman, 2013), and with the spatial distribution of the main fixed and mobile air pollution sources. The choice of a $2 \times 2 \mathrm{~m}$ square grid assures models of a fine level of definition compatible with the study's aims. The models were based on annual daily average inputs to even out temporal fluctuations in pollutant concentrations, especially $\mathrm{NO}_{2}$ values. The averaged values are most compatible with chronic exposure assessments for urban populations and the long-term perspective implied by the living neighborhood. This approach is consistent with other model-based environmental health studies (Latza et al., 2009), (Zhang and Batterman, 2013), (Beelen et al., 2014) and facilitates comparison with annual (or long-term) legal thresholds (World Health
Organization Europe, 2000), (World Health Organizgation Europe, 2005a).

All the calculated average annual air pollution levels are below the thresholds fixed by French legislation (Code de l'environnement - Titre R22, 2013). They are also at or below the European annual average for urban background concentrations (EEA, 2011a) and respect values the World Health Organization advises for protecting public health (World Health Organization, 2014). These values indicate that Besançon is a moderately polluted area. Due to the general trend in pollution reduction observed across Europe (EEA, 2011a), in the future these moderate pollution levels may be found in cities that are currently considered highly polluted. These results prove that the choice of exposure assessment technique is of great importance, even at moderate to low levels of pollution, and may be even more significant in highly polluted areas.

The exposure assessment techniques were chosen to reflect the differences between approaches to outdoor air exposure assessment (Hoek et al., 2002), (Hoffmann et al., 2009), (Cesaroni et al., 2008), (Huynh et al., 2006), (Bell et al., 2007). The address-point technique represents exposure at a single point, supposedly located at the entrance of a building (Cayo and Talbot, 2003), (Bonner et al., 2003), (Tenailleau et al., 2015), although the distance between the address point and the building entrance may be great (Tenailleau et al., 2015). The building exterior perimeter technique assesses dwelling exposure at the outdoor-indoor interface. Census blocks and census block groups are small and medium administrative areas, making it possible to assess exposure easily but in the aggregate, by attributing the same exposure to every subject or building in the same administrative area. Lastly, buffer techniques represent the immediate living neighborhoods of the subjects and are used as proxies for the adult "walking neighborhood" where subjects circulate to meet most of their daily needs (Smith et al., 2010). A maximum of $400 \mathrm{~m}$ was retained for the straight-line buffers, in line with other studies that consider the usual $1.6 \mathrm{~km}$ (one mile) buffer inappropriate for European cities (Smith et al., 2010), (Forsyth et al., 2008). Despite their common usage, circular buffers may not be the best choice for representing neighborhoods. The residential neighborhood is rarely circular and is actually conditioned by urban parameters (morphology, topography, land-use, etc.) as 
well as by individual subject parameters (national culture, living habits, activity pattern, mobility, socio-economic level, etc.) (Chaix et al., 2009), (Smith et al., 2010). The ideal exposure assessment technique would be specifically designed, in both size and shape, to account for each subject's particular definition of the neighborhood based on how he or she uses it. However, circular buffers remain an appealing alternative when information on the population's use of the neighborhood is lacking, as in this study.

Some studies have already looked at the impact of model scale on air pollution exposure assessment, showing either an impact (Pedersen et al., 2013), (Batterman et al., 2014) or an absence of impact (Stroh et al., 2007). To our knowledge, this study is the first to explore differential measurement errors resulting from the definition of the neighborhood, especially in the context of a medium-sized European city. A similar study was conducted on noise in the same city (Tenailleau et al., 2015). For both noise and air pollution, such differential measurement errors can lead to a misclassification of subject exposure estimates, and ultimately to a biased estimate of the relationship between exposure and health. A change in the scale of neighborhood definition could result in the overestimation or underestimation of exposure estimates according to the neighborhood's physical and socioeconomic characteristics.

Studies exploring a neighborhood's physical and socioeconomic characteristics and air pollution exposure estimates at a single neighborhood scale have shown them to be in a direct relationship (Lyons et al., 1990), (Tang and Wang, 2007). Unsurprisingly, our results indicate that the distance between individual buildings and the nearest road is by far the main contributor to the differential measurement bias for all pollutants. Decreased exposure due to scale change often occurs along major roads, and may be explained by the dilution of the source contribution in the averaged exposure estimate for a larger area. The opposite happens for buildings located in the interior of city blocks in instances when a larger definition of neighborhood, including high contribution sources such as a major highway, is chosen. Most of the points showing no change, regardless of neighborhood scale, are located on the urban fringe away from main roads, where exposure estimates would not be influenced by the inclusion of new sources as the definition of neighborhood is expanded. Although a direct relationship between the distance from a road and exposure estimates has been previously demonstrated (Van Vliet et al., 1997), (Roorda-Knape et al., 1998), (Fischer et al., 2000), (Janssen et al., 2001), the literature contains no results concerning the differential impact of variations in scale.

Associations between deprivation indices and air pollution levels have been found in the E.U. (Kohlhuber et al., 2006), (Chaix et al., 2006), (Briggs et al., 2008), the U.S. (Evans and Marcynyszyn, 2004), (O'Neill et al., 2003), (Hajat et al., 2013), (Gray et al., 2013) and Asia (Yi et al., 2010). Only one study (Stroh et al., 2005) focused on the effect of scale (county and city) on the relationship between deprivation indices and $\mathrm{NO}_{2}$ concentrations, highlighting the significant and more complex impact of the chosen scale. But to our knowledge, the differential impact of socioeconomic status on air pollution exposure assessment has not been observed in any previous study. Without being able to explain this effect, we observed that the consequences of a change in scale differ between disadvantaged and more affluent areas. As neighborhood scale increases, so do exposure values assigned to the buildings in the most disadvantaged areas, whereas those given to buildings in advantaged areas decrease.

Environmental epidemiology relies on accurate exposure assessment. Underestimating the impact of the definition of neighborhood could lead to errors in exposure assessment and thus also impact resulting public health studies, health risk assessments, and decision-making. Our results show that understanding the chosen exposure assessment technique and its potential to impact exposure estimates is of prime importance to the investigator. Each technique corresponds to a particular conception of the neighborhood and its exposure situation. They consequently should be chosen according to study conditions and to subject behavior and living conditions.

Letters along boxplots indicate absence of statistical differences. Boxplots with no letters are statistically different from all others. Boxplots belonging to the same group (example: "a") show no statistical differences. Boxplots belonging to several groups (example: "bc") show no statistical difference with either group (b and c).

\section{Author contributions}

Dr. Quentin M Tenailleau - Ph.D. student at the time manuscript was written; GIS modeling, statistical analysis, and preparation of manuscript.

Dr. Frédéric Mauny - Ph.D. \& M.D. in public health, specialty exposure sciences; doctoral committee member and co-supervisor of the scientific project and statistical analysis. Manuscript coauthor.

Dr. Daniel Joly - Ph.D. in geographical sciences, specialty climatology; project advisor for GIS modeling, pollutant modeling, and geographical sciences.

Mr. Stephane François - Scientific Engineer at the local organization designated by the French government to monitor air pollution; pollutant emission modelling.

Dr. Nadine Bernard - Ph.D. in environmental sciences, specialty air pollution; dissertation advisor, co-supervisor of the scientific study, and advisor on air pollutant behavior. Manuscript coauthor.

All authors contributed to the writing of the manuscript, and have approved the final version.

\section{Funding source}

Quentin Tenailleau was a Ph.D. student funded by a grant from the city of Besançon while the article was in preparation.

\section{Acknowledgments}

The authors would like to thank the city services and urban community of Besançon (CAGB), the Besançon Urban Development Agency (AUDAB) and the Departmental Division of Public Works (DDE) for their technical support. The study was supported by a grant from the city of Besançon.

\footnotetext{
Appendix 1. Map of Besançon and environs indicating land use inside and outside the city limits. Insert map shows the location of Besançon in eastern France
} 


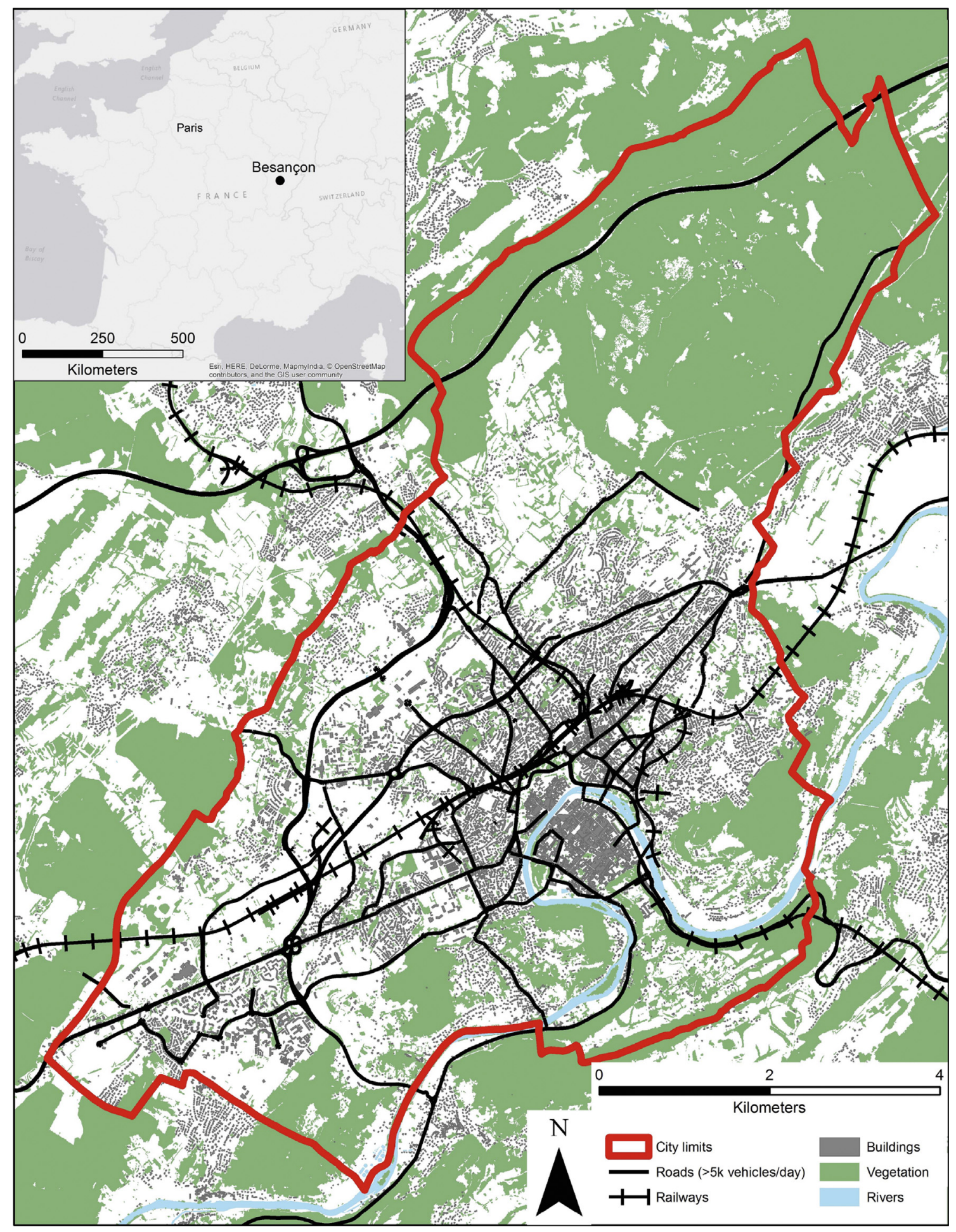


Appendix 2. The research procedure for air pollutant models:

from sources to exposure estimates.

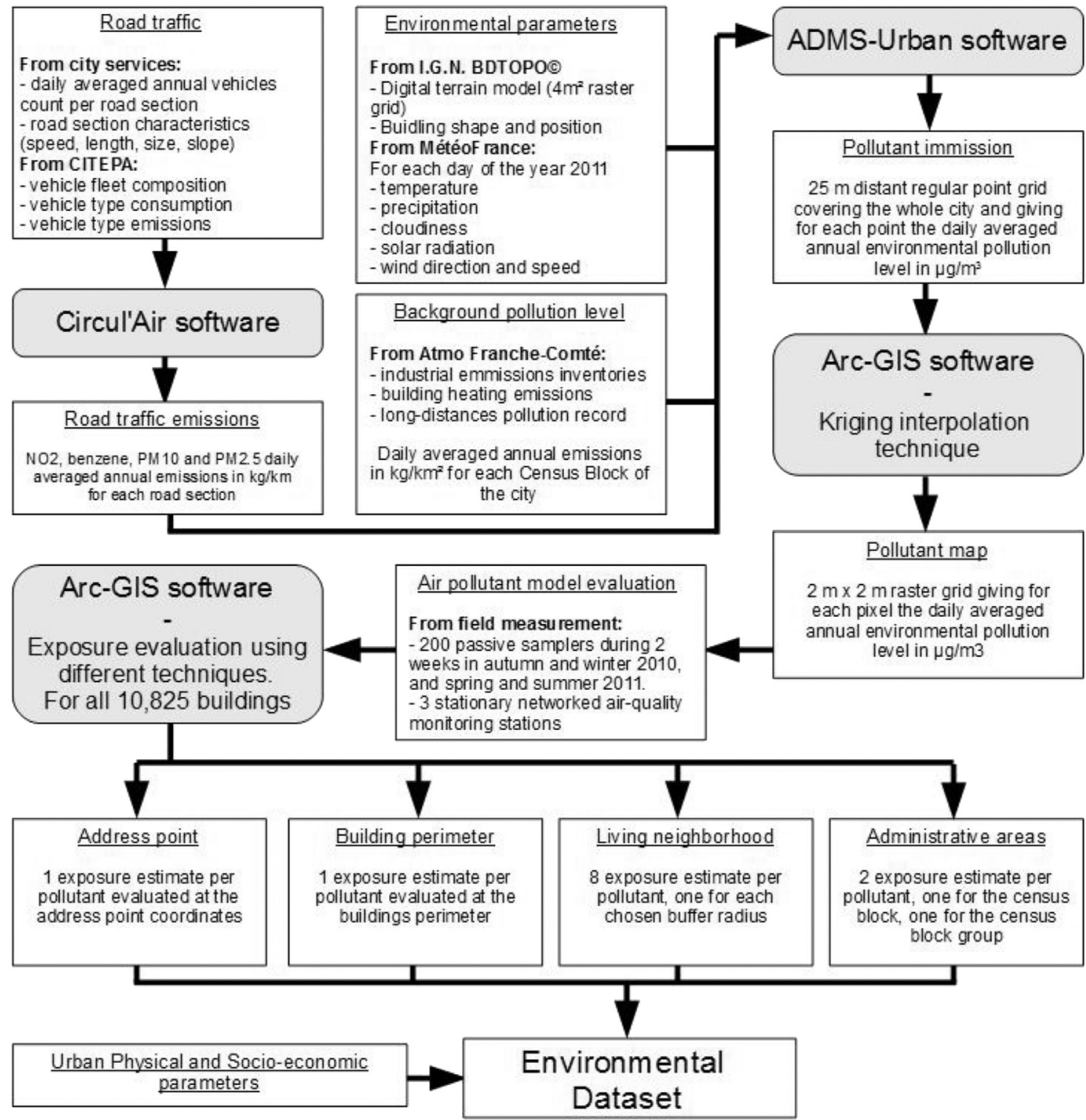




\section{Appendix 3. Detailed information on the selection of the building sample}

According to the National Institute of Geography database (BD TOPO $^{\circledR}$ for 2011), Besançon contains 13,007 buildings within its city limits. All buildings were identified by use as "administrative building," "industrial building," or "other." When unable to identify precisely which of the "other" buildings were inhabited, all those over $4 \mathrm{~m}$ high with a surface area over $20 \mathrm{~m}^{2}$ were considered to be inhabitable (according to French legislation: (Code de la construction et de l'habitation, 2012)). Of the 12,102 inhabitable buildings thus obtained, 1277 buildings were excluded from the sample because they were within $400 \mathrm{~m}$ of the city's outer boundary. This spatial exclusion was applied to ensure the quality of the statistical analysis and the comparability of obtained statistical results. It aims to avoid boundary effects for lack of modeled pollution levels outside the city limits. This lack of data would have impacted exposure assessment, especially for exposure estimates obtained by techniques using large buffers. Consequently, this study's final sample consists of 10,825 buildings.

\section{Appendix 4. Typological map of Besançon urban area}

Each census block was characterized using an urban typology based on build-up pattern, building density, and human land use (Houot, 1999). Five types of census block were defined:

- Individual Housing areas cover most of the city. They are mostly dominated by pre-1900 to recent individual houses.

- Densely Urbanized Areas cover less than 5\% of the city. They are characterized by old urbanization with a mostly hippodamian urban plan, very dense construction with many narrow one-way streets. Building height, size and shape vary considerably depending on the period of construction, and many services and shops are located on the ground floor of inhabitable buildings.

- Social Housing areas cover less than $5 \%$ of the city and are heavily dominated by high-rise blocks of public housing, more or less isolated from each other.

- Mixed Residential Areas cover around 20\% of the city and show a wide variety of morphology and land-use. The landscape is mostly occupied by individual houses but most inhabitants actually live in 1950s-era social housing dotting the area.

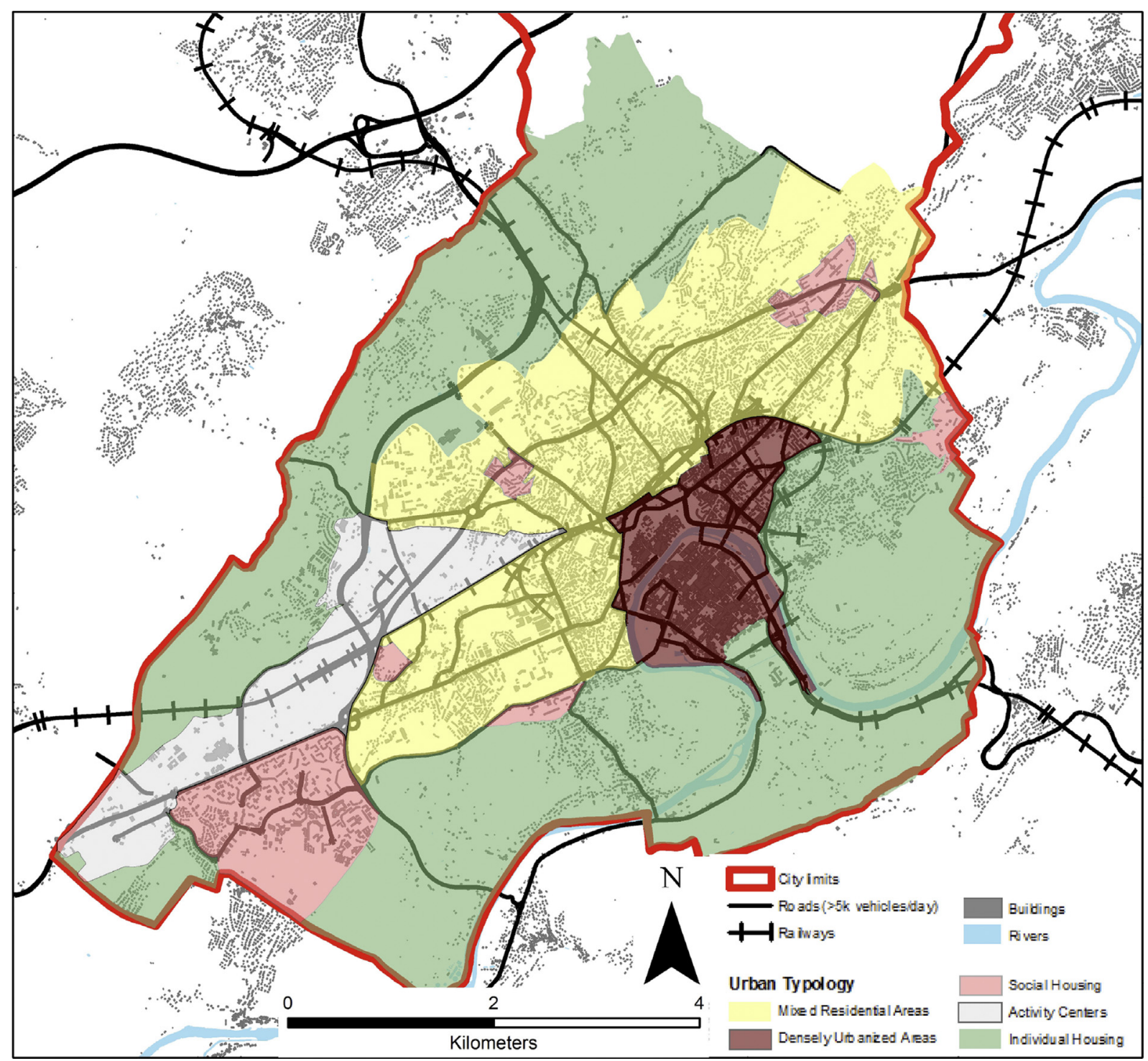


- Activity Center areas cover around 6\% of the city and are mostly located in the southwestern part, along the main transportation arteries. They are characterized by low commercial or industrial buildings with large surface areas.

\section{Appendix 5. Land use and building morphology by urban type in Besançon}

\begin{tabular}{|c|c|c|c|c|c|}
\hline & $\begin{array}{l}\text { Percentage of } \\
\text { the city area }\end{array}$ & Population & $\begin{array}{l}\text { Built } \\
\text { surface }\end{array}$ & $\begin{array}{l}\text { Road } \\
\text { surface }\end{array}$ & $\begin{array}{l}\text { Average } \\
\text { building } \\
\text { ground } \\
\text { surface area }\end{array}$ \\
\hline City & $100 \%$ & $\begin{array}{l}115,879 \\
\text { hab }\end{array}$ & $6 \%$ & $5 \%$ & $316 \mathrm{~m}^{2}$ \\
\hline \multicolumn{6}{|l|}{ Value per urban type } \\
\hline $\begin{array}{l}\text { Densely urbanized } \\
\text { area }\end{array}$ & $5 \%$ & $21 \%$ & $28 \%$ & $7 \%$ & $1186 \mathrm{~m}^{2}$ \\
\hline $\begin{array}{l}\text { Mixed residential } \\
\text { area }\end{array}$ & $20 \%$ & $43 \%$ & $11 \%$ & $6 \%$ & $272 \mathrm{~m}^{2}$ \\
\hline Social housing & $5 \%$ & $24 \%$ & $11 \%$ & $8 \%$ & $503 \mathrm{~m}^{2}$ \\
\hline Individual housing & $38 \%$ & $12 \%$ & $3 \%$ & $3 \%$ & $189 \mathrm{~m}^{2}$ \\
\hline Activity center & $6 \%$ & $1 \%$ & $4 \%$ & $6 \%$ & $455 \mathrm{~m}^{2}$ \\
\hline
\end{tabular}

\section{References}

Auchincloss, A.H., Gebreab, S.Y., Mair, C., Diez Roux, A.V., 2012. A review of spatial methods in epidemiology, 2000-2010. Annu. Rev. Public Health 33, 107-122. http://dx.doi.org/10.1146/annurev-publhealth-031811-124655.

Batterman, S., Chambliss, S., Isakov, V., 2014. Spatial resolution requirements for traffic-related air pollutant exposure evaluations. Atmos. Environ. 94, 518-528. http://dx.doi.org/10.1016/j.atmosenv.2014.05.065.

Beelen, R., Raaschou-Nielsen, O., Stafoggia, M., Andersen, Z.J., Weinmayr, G., Hoffmann, B., Wolf, K., Samoli, E., Fischer, P., Nieuwenhuijsen, M., Vineis, P., Xun, W.W., Katsouyanni, K., Dimakopoulou, K., Oudin, A., Forsberg, B., Modig, L., Havulinna, A.S., Lanki, T., Turunen, A., Oftedal, B., Nystad, W., Nafstad, P., De Faire, U., Pedersen, N.L., Östenson, C.-G., Fratiglioni, L., Penell, J., Korek, M. Pershagen, G., Eriksen, K.T., Overvad, K., Ellermann, T., Eeftens, M., Peeters, P.H, Meliefste, K., Wang, M., Bueno-de-Mesquita, B., Sugiri, D., Krämer, U., Heinrich, J., de Hoogh, K., Key, T., Peters, A., Hampel, R., Concin, H., Nagel, G., Ineichen, A., Schaffner, E., Probst-Hensch, N., Künzli, N., Schindler, C. Schikowski, T., Adam, M., Phuleria, H., Vilier, A., Clavel-Chapelon, F., Declercq, C. Grioni, S., Krogh, V., Tsai, M.-Y., Ricceri, F., Sacerdote, C., Galassi, C., Migliore, E., Ranzi, A., Cesaroni, G., Badaloni, C., Forastiere, F., Tamayo, I., Amiano, P. Dorronsoro, M., Katsoulis, M., Trichopoulou, A., Brunekreef, B., Hoek, G., 2014. Effects of long-term exposure to air pollution on natural-cause mortality: an analysis of 22 European cohorts within the multicentre ESCAPE project. Lancet 383 (9919), 785-795. http://dx.doi.org/10.1016/S0140-6736(13)62158-3.

Bell, M.L., Ebisu, K., Belanger, K., 2007. Ambient air pollution and low birth weight in Connecticut and Massachusetts. Env. Health Perspect. 115, 1118-1124.

Boddy, M., 1999. Geographical economics and urban competitiveness: a critique. Urban Stud. 36, 811-842.

Bonner, M.R., Han, D., Nie, J., Rogerson, P., Vena, J.E., Freudenheim, J.L., 2003. Positional accuracy of geocoded addresses in epidemiologic research. Epidemiology $14,408-412$

Briggs, D., Abellan, J.J., Fecht, D., 2008. Environmental inequity in England: small area associations between socio-economic status and environmental pollution. Soc. Sci. Med. 67, 1612-1629. http://dx.doi.org/10.1016 j. socscimed 2008.06.040.

Brunekreef, B., Holgate, S.T., 2002. Air pollution and health. Lancet 360, 1233-1242.

Cambridge Environmental Research Consultants, 2014. ADMS-urban presentation [WWW Document]. ADMS-urban present. http://www.cerc.co.uk/ environmental-software/ADMS-Urban-model.html (accessed 10.09.14.).

Cayo, M.R., Talbot, T.O., 2003. Positional error in automated geocoding of residential addresses. Int. J. Health Geogr. 2, 10.

Centro di Ricerche Ambientali - Padova, 2006. Radiello User's Manual.

Cesaroni, G., Badaloni, C., Porta, D., Forastiere, F., Perucci, C.A., 2008. Comparison between various indices of exposure to traffic-related air pollution and thei impact on respiratory health in adults. Occup. Environ. Med. 65, 683-690.

Chaix, B., Gustafsson, S., Jerrett, M., Kristersson, H., Lithman, T., Boalt, Å., Merlo, J. 2006. Children's exposure to nitrogen dioxide in Sweden: investigating environmental injustice in an egalitarian country. J. Epidemiol. Community Health
60, 234-241.

Chaix, B., Merlo, J., Evans, D., Leal, C., Havard, S., 2009. Neighbourhoods in ecoepidemiologic research: delimiting personal exposure areas. A response to Riva, Gauvin, Apparicio and Brodeur. Soc. Sci. Med. 69, 1306-1310.

Clougherty, J.E., Wright, R.J., Baxter, L.K., Levy, J.I., 2008. Land use regression modeling of intra-urban residential variability in multiple traffic-related air pollutants. Env. Health 7, 17.

Code de la construction et de l'habitation, 2012. Code de la construction et de l'habitation.

Code de l'environnement - Titre R22, 2013. Air et atmosphère.

Duncan, D.T., Kawachi, I., Subramanian, S.V., Aldstadt, J., Melly, S.J., Williams, D.R., 2014. Examination of how neighborhood definition influences measurements of youths' access to tobacco retailers: a methodological note on spatial misclassification. Am. J. Epidemiol. 179, 373-381. http://dx.doi.org/10.1093/aje/ kwt251.

EEA, 2011a. Air Quality in Europe. European Environment Agency, Luxemburg (Luxemburg) (Technical report).

EEA, 2011b. The Application of Models under the European Union's Air Quality Directive. European Environmental Agency, Luxembourg (Luxembourg).

EEA, 2009. The Contribution of Transport to Air Quality. TERM 2009: Indicators Tracking Transport and Environment in the European Union. European Environment Agency, Luxemburg (Luxemburg).

Ehrlich, P.R., Holdren, J.P., 1974. Human population and the global Environment: population growth, rising per capita material consumption, and disruptive technologies have made civilization a global ecological force. Am. Sci. 62, $282-292$.

EMEP/EEA, 2013. EMEP/EEA Air Pollutant Emission Inventory Guidebook 2013. Technical Guidance to Prepare National Emission Inventories. European Monitoring and Evaluation Programme \& European Environment Agency, Luxemburg (Luxemburg).

EMEP/EEA, 2009. EMEP/EEA Air Pollutant Emission Inventory Guidebook 2009. Technical Guidance to Prepare National Emission Inventories. European Monitoring and Evaluation Programme \& European Environment Agency, Luxemburg (Luxemburg).

European Commission, 2004. How Europeans Spend their Time. Everyday Life of Women and Men. European Commission, Luxembourg (Luxembourg).

Evans, G.W., Marcynyszyn, L.A., 2004. Environmental Justice, Cumulative environmental risk, and health among low- and Middle-Income children in Upstate New York. Am. J. Public Health 94, 1942-1944.

Fischer, P., Hoek, G., van Reeuwijk, H., Briggs, D., Lebret, E., Van Wijnen, J., Kingham, S., Elliott, P., 2000. Traffic-related differences in outdoor and indoor concentrations of particles and volatile organic compounds in Amsterdam. Atmos. Environ. 34, 3713-3722.

Forsyth, A., Hearts, M., Oakes, J., Schmitz, K., 2008. Design and destinations: factors influencing walking and total physical activity. Urban Stud. 45, 1973-1996.

Giffinger, R., Fertner, C., Kramar, H., Meijers, E., 2007. City-ranking of European medium-sized cities. Cent. Reg. Sci. 1-12. Vienna UT.

Gray, S.C., Edwards, S.E., Miranda, M.L., 2013. Race, socioeconomic status, and air pollution exposure in North Carolina. Environ. Res. 126, 152-158. http:// dx.doi.org/10.1016/j.envres.2013.06.005.

Hajat, A., Diez-Roux, A.V., Adar, S.D., Auchincloss, A.H., Lovasi, G.S., O'Neill, M.S., Sheppard, L., Kaufman, J.D., 2013. Air pollution and individual and neighborhood socioeconomic status: evidence from the Multi-ethnic study of atherosclerosis (MESA). Environ. Health Perspect. 121, 1325-1333. http://dx.doi.org/ 10.1289/ehp.1206337.

Health Effects Institute, 2000. The National Morbidity, Mortality, and Air Pollution Study. Part II: Morbidity and Mortality from Air Pollution in the United States. Health Effects Institute, Cambridge (MA, USA).

Hoek, G., Brunekreef, B., Goldbohm, S., Fischer, P., van den Brandt, P.A., 2002. Association between mortality and indicators of traffic-related air pollution in the Netherlands: a cohort study. Lancet 360, 1203-1209.

Hoffmann, B., Moebus, S., Möhlenkamp, S., Stang, A., Lehmann, N., Dragano, N., Schmermund, A., Memmesheimer, M., Mann, K., Erbel, R., Jöckel, K.-H., 2009. Residential exposure to traffic is associated with coronary atherosclerosis. Circulation 116, 489-496.

Houot, H., 1999. Approche géographique des nuisances sonores urbaines: méthodologie d'aide à la prise en compte des nuisances sonores en aménagement urbain. Université de Franche-Comté.

Huynh, M., Woodruff, T.J., Parker, J.D., Schoendorf, K.C., 2006. Relationships between air pollution and preterm birth in California. Paediatr. Perinat. Epidemiol. 20, 454-461.

INSEE, 2013a. Definition of "Statistical block" [WWW Document] (accessed 11.01.13.). http://www.insee.fr/en/methodes/default.asp?page=definitions/ilot. htm.

INSEE, 2013b. Definition of “IRIS" [WWW Document] (accessed 11.01.13.). http:// www.insee.fr/en/methodes/default.asp?page=definitions/iris.htm.

INSEE, 2013c. Definition of "foreigner" [WWW Document] (accessed 12.06.14.). http://www.insee.fr/en/methodes/default.asp?page=definitions/etranger.htm.

INSEE, 2013d. Definition of "immigrant" [WWW Document] (accessed 12.06.14.) http://www.insee.fr/en/methodes/default.asp?page=definitions/immigre.htm.

INSEE, 2009. Results of the population census - 2009 [WWW Document] (accessed 11.01.13.). http://www.recensement.insee.fr/basesInfracommunales.action.

Janssen, N.A., van Vliet, P.H., Aarts, F., Harssema, H., Brunekreef, B., 2001. Assessment of exposure to traffic related air pollution of children attending schools near motorways. Atmos. Environ. 35, 3875-3884. http://dx.doi.org/10.1016/ 
S1352-2310(01)00144-3.

Klepeis, N.E., Nelson, W.C. Ott, W.R., Robinson, J.P., Tsang, A.M., Switzer, P. Behar, J.V., Hern, S.C., Engelmann, W.H., 2001. The National Activity Pattern Survey (NHAPS): a ressource for assessing exposure to environmental pollutants. J. Expo. Anal. Environ. Epidemiol. 11, 231-252.

Kohlhuber, M., Mielck, A., Weiland, S.K., Bolte, G., 2006. Social inequality in perceived environmental exposures in relation to housing conditions in Germany. Environ. Res. 101, 246-255.

Latza, U., Gerdes, S., Baur, X., 2009. Effects of nitrogen dioxide on human health: systematic review of experimental and epidemiological studies conducted between 2002 and 2006. Int. J. Hyg. Environ. Health 212, 271-287.

Lyons, T., Kenworthy, J., Newman, P., 1990. Urban structure and air pollution. Atmos. Environ. Part B Urban Atmos. 24, 43-48.

Nieuwenhuijsen, M.J., 2003. Exposure Assessment in Occupational \& Environmental Epidemiology. Oxford University Press.

Nieuwenhuijsen, M., Paustenbach, D., Duarte-Davidson, R., 2006. New developments in exposure assessment: the impact on the practice of health risk assessment and epidemiological studies. Environ. Int. 32, 996-1009.

O'Neill, M.S., Jerrett, M., Kawachi, I., Levy, J.I., Cohen, A.J., Gouveia, N., Wilkinson, P., Fletcher, T., Cifuentes, L., Schwartz, J., 2003. Health, wealth, and air pollution: advancing theory and methods. Environ. Health Perspect. 111, 1861.

Passam ag, 2010. Nitrogen Dioxide Passive Sampler's User Manual.

Pedersen, M., Siroux, V., Pin, I., Charles, M.A., Forhan, A., Hulin, A., Galineau, J. Lepeule, J., Giorgis-Allemand, L., Sunyer, J., Annesi-Maesano, I., Slama, R., 2013. Does consideration of larger study areas yield more accurate estimates of air pollution health effects? An illustration of the bias-variance trade-off in air pollution epidemiology. Environ. Int. 60, 23-30. http://dx.doi.org/10.1016/ j.envint.2013.07.005

Pujol, S., Houot, H., Antoni, J.P., Mauny, F., 2012. Linking traffic and noise models to explore spatio-temporal distribution of noise pollution: an example in Besancon (France). In: Proceedings of the 19th International Congress on Sound and Vibration. Presented at the 19th International Congress on Sound and Vibration, Vilnuis (Lithuania).

Roorda-Knape, M.C., Janssen, N.A., De Hartog, J.J., Van Vliet, P.H., Harssema, H., Brunekreef, B., 1998. Air pollution from traffic in city districts near major motorways. Atmos. Environ. 32, 1921-1930.

Rupprecht \& Patashnick Co, Inc, 2009. Operating Manual - Partisol-plus Model 2025 Sequential Air Sampler.

Selden, T.M., Song, D., 1994. Environmental quality and Development: Is there a Kuznets curve for air pollution emissions? J. Environ. Econ. Manag. 27, 147-162.

Shukla, V., Parikh, K., 1992. The environmental consequences of urban growth: Cross-national perspectives on economic development, air pollution, and city size. Urban Geogr. 13, 422-449.

Smith, G. Gidlow, C., Davey, R., Foster, C., 2010. What is my walking neighbourhood? A pilot study of English adults' definitions of their local walking neighbourhoods. Int. J. Behav. Nutr. Phys. Act. 7, 34-42.

Stroh, E., Harrie, L., Gustafsson, S., 2007. A study of spatial resolution in pollution exposure modelling. Int. J. Health Geogr. 6, 1-13. http://dx.doi.org/10.1186/ 1476-072X-6-19.

Stroh, E., Oudin, A., Gustafsson, S., Pilesjö, P., Harrie, L., Strömberg, U., Jakobsson, K., 2005. Are associations between socio-economic characteristics and exposure to air pollution a question of study area size? An example from Scania, Sweden Int. J. Health Geogr. 4, 1-13. http://dx.doi.org/10.1186/1476-072X-4-30.

Tang, U.W., Wang, Z.S., 2007. Influences of urban forms on traffic-induced noise and air pollution: results from a modelling system. Environ. Model. Softw. 22, 1750-1764.

Tenailleau, Q.M., Bernard, N., Pujol, S., Houot, H., Joly, D., Mauny, F., 2015. Assessing residential exposure to urban noise using environmental models: does the size of the local living neighborhood matter? J. Expo. Sci. Environ. Epidemiol. 25, 89-96. http://dx.doi.org/10.1038/jes.2014.33.

Van Vliet, P.H., Knape, M., de Hartog, J., Janssen, N., Harssema, H., Brunekreef, B., 1997. Motor vehicle exhaust and chronic respiratory symptoms in children living near freeways. Environ. Res. 74, 122-132. http://dx.doi.org/10.1006/ enrs.1997.3757.

World Health Organization, 2014. Ambient (Outdoor) Air Quality and Health, Fact Sheet $\mathrm{N}^{\circ} 313$ [WWW Document]. World Health Organ. http://www.who.int/ mediacentre/factsheets/fs313/en/.

World Health Organization, 2013. Outdoor Air Pollution a Leading Environmental Cause of cancer Deaths.

World Health Organizgation Europe, 2005a. Air Quality Guidelines Global Update. World Health Organization - Regional Office for Europe, Copenhagen (Denmark).

World Health Organization Europe, 2005b. Health Effects of Transport-related Air Pollution. WHO Regional Office Europe.

World Health Organization Europe, 2003. Health Aspects of Air Pollution with Particulate Matter, Ozone and Nitrogen Dioxide. World Health Organization Regional Office for Europe. Copenhagen (Denmark).

World Health Organization Europe, 2000. Air Quality Guidelines for Europe. World Health Organization - Regional Office for Europe, Copenhagen (Denmark).

Yi, O., Kim, H., Ha, E., 2010. Does area level socioeconomic status modify the effects of PM10 on preterm delivery? Environ. Res. 110, 55-61. http://dx.doi.org/ 10.1016/j.envres.2009.10.004.

Zhang, K., Batterman, S., 2013. Air pollution and health risks due to vehicle traffic. Sci. Total Environ. 450-451, 307-316. 